\title{
Lymphocyte proliferation kinetics in malnourished children measured by differential chromatid staining
}

\author{
BY P. BALAKRISHNA MURTHY ${ }^{1 *}$, M. ABDUL RAHIMAN ${ }^{2}$ \\ AND P. G. TULPULE ${ }^{1}$ \\ ${ }^{1}$ National Institute of Nutrition, Indian Council of Medical Research, Jamai-Osmania \\ PO, Hyderabad-500 007, A.P. India, and ${ }^{2}$ Department of Bio-sciences, Mangalore \\ University, Konaje, Mangalagangotri, Mangalore-574 152, India
}

(Received 28 May 1981 - Accepted 9 December 1981)

\begin{abstract}
1. Utilizing the bromodeoxyuridine differential-chromatid labelling technique the in vitro proliferation of lymphocytes from children with kwashiorkor was followed in phytohaemagglutinin-stimulated cultures and compared with controls.

2. Analyses of first, second and third or subsequent division cells as a function of culture time between 40 and $96 \mathrm{~h}$ showed that cell-cycle duration was prolonged in kwashiorkor cultures. The extent of this increase was approximately $4.5 \mathrm{~h}$ for the first-division cells and $1.5 \mathrm{~h}$ for third-division cells.

3. The peak for second-division cells was depressed in kwashiorkor cultures.

4. A decreased number of third or subsequent-division cells was observed in kwashiorkor cultures at all time points studied.

5. These findings suggest that the loss in lymphocyte activity to PHA in malnourished children in general could be due to an increase in cell-cycle duration of responding lymphocytes.
\end{abstract}

It is well established that in children suffering from protein-energy malnutrition (PEM), cell-mediated immunity (CMI) is decreased (Reddy et al. 1976; Schopfer \& Douglas, 1976; Gross \& Newberne, 1980). It has been suggested that this decrease in CMI could be the result of: (1) a decrease in the number of thymus-dependent lymphocytes (Chandra, 1974; Bang et al. 1975; Ferguson et al. 1975; Reddy et al. 1976; Das et al. 1977) and (2) an impaired response of lymphocytes to phytohaemagglutinin (PHA), as measured by tritiated thymidine $\left(\left[{ }^{3} \mathrm{H}\right]-\mathrm{Tdr}\right)$ incorporation (Sellmeyer et al. 1972; Chandra, 1974; Schopfer \& Douglas, 1976) or by scoring the number of blast-transformed cells (Smythe et al. 1971; Burgess et al. 1974; Kulapongs et al. 1977). The latter observation suggests a membrane defect (Schopfer \& Douglas, 1976) or altered receptor binding affinities in PHA-responding lymphocytes or both in PEM. It is not known whether changes in cell-cycle duration could also contribute to the observed impaired lymphocyte response to PHA. Information on the in vitro kinetics of lymphocyte proliferation in PEM is not available. Previous studies (Mathur \& Deo, 1976; Deo, 1978) on the cellular proliferation in vivo have shown that in undernourished rats the cell-cycle duration in various organs is prolonged. These studies, however, involved pulse labelling of cells with $\left[{ }^{3} \mathrm{H}\right]-\mathrm{Tdr}$ and subsequent autoradiographic analysis. The usefulness of this method is limited because of the possible inhibitory effect of incorporated $\left[{ }^{3} \mathrm{H}\right]$-Tdr on cellular proliferation and the tedious nature of autoradiographic analysis (Schneider et al. 1977). The recently-developed bromodeoxyuridine (BUdr) differential-labelling techniques (Latt, 1974; Perry \& Wolff, 1974; Wolff \& Perry, 1974) have made the analysis of proliferating cells easy, without the use of autoradiography. These techniques essentially involve the labelling of replicating chromosomes with a non-inhibitory concentration of BUdr (a base analogue of thymidine in DNA). Metaphase of cells which have undergone one, two and three or more divisions in the presence of this analogue exhibit characteristic staining properties when stained with Hoechst 33258 (Tice et al. 1975) or the

$$
\text { * For reprints. }
$$


Hoechst-Giemsa method (Perry \& Wolff, 1974). We therefore, have utilized one of these cytogenetic techniques to follow the PHA-stimulated proliferation kinetics of lymphocytes from children with kwashiorkor (a severe form of PEM), in an attempt to explain the observed impaired response of these cells to PHA.

\section{SUBJECTS AND METHODS}

Six children suffering from kwashiorkor were investigated. They had severe growth retardation,'oedema and hypoalbuminaemia and conformed to descriptions given earlier (Venkatachalam et al. 1954). A majority of these children had either respiratory or gastrointestinal infection. Five apparently-normal boys and girls with body-weights ranging between 80 and $100 \%$ of the standard weight-for-age (Nelson, 1969), served as controls. All children were aged between 1 and 5 years.

Lymphocytes in whole blood were cultured in RPMI - 1640 containing foetal calf serum (200 ml/l), antibiotics $(100 \mathrm{ml} / \mathrm{u}$. penicillin and $100 \mathrm{ml} / \mu \mathrm{g}$ streptomycin $), 2 \mathrm{mM}$-L-glutamine and PHA (Wellcome). BUdr $(20 \mu \mathrm{M})$ was added to all the tubes at the beginning of the cultures and incubated at $37^{\circ}$ in the dark. At this concentration of BUdr, no inhibition of lymphocytes was seen in both control and kwashiorkor. The cultures were harvested at $8 \mathrm{~h}$ intervals from the $2 \mathrm{nd}$ to the 4 th day. Colchicine $(1.0 \mu \mathrm{g} / \mathrm{ml})$ was added during the last $2 \mathrm{~h}$ of incubation. Chromosome preparations were made as described earlier (Murthy \& Prema, 1979), and stained by the Hoechst-Giemsa method (Perry \& Wolff, 1974). For each individual, duplicate cultures were harvested at all intervals. One hundred consecutive metaphases were analysed per culture at each time-point and classified as having undergone either one, two or three divisions depending on the differential-chromatid staining characteristics (Craig-Holmes \& Shaw, 1976; Hatcher \& Hook, 1976; Giulotto et al. 1980). The third-division cells were pooled with the subsequent mitoses because of the limited number of subsequent division cells (four or more divisions). The regression lines for the logarithmic disappearance of first-division cells and the appearance of third-division cells $v$. culture time were calculated by least square analysis. The statistical analyses were carried out by analysis of covariance technique.

\section{RESULTS}

In Fig. $1(a, b)$ are presented the distributions of first, second and third or subsequent divisions at different culture times studied. In both normal and kwashiorkor cultures, the first-division cells comprised $100 \%$ at $40 \mathrm{~h}$. They disappeared by $88 \mathrm{~h}$ in normal cultures in contrast to their continued presence $(6-12 \%$ of the total metaphases) even at $96 \mathrm{~h}$ in kwashiorkor cultures. The second-division cells made their appearance at $48 \mathrm{~h}$ in both normal and kwashiorkor cultures. Also the peak for second-division cells was achieved at identical points $(64 \mathrm{~h})$. The peak was depressed and flattened in kwashiorkor cultures as against a sharp peak in normal cultures, although the relative proportion of second-division cells was larger at $56 \mathrm{~h}$ in malnourished children, apparently indicating an earlier appearance of these cells. Although the third or subsequent-division cells were observed at $48 \mathrm{~h}$ in normal cultures, they were only evident at $56 \mathrm{~h}$ in kwashiorkor cultures. Further, by $96 \mathrm{~h}$, $97-100 \%$ of the total metaphases were enumeiated as having completed three or more divisions in normal cultures as against only $63-83 \%$ of such cells in kwashiorkor cultures. A significantly decreased number of third-division cells was observed at all time-points studied (details of significance levels are not presented here).

The regression equations for the disappearance of first-division cells and the appearance of third- or subsequent-division cells are presented in Tables 1 and 2. By extrapolating back to $100 \%$, the time of initiation of the disappearance of first-division cells was calculated to be 46.97 and $46.95 \mathrm{~h}$ for normal and kwashiorkor cultures respectively. A significant 

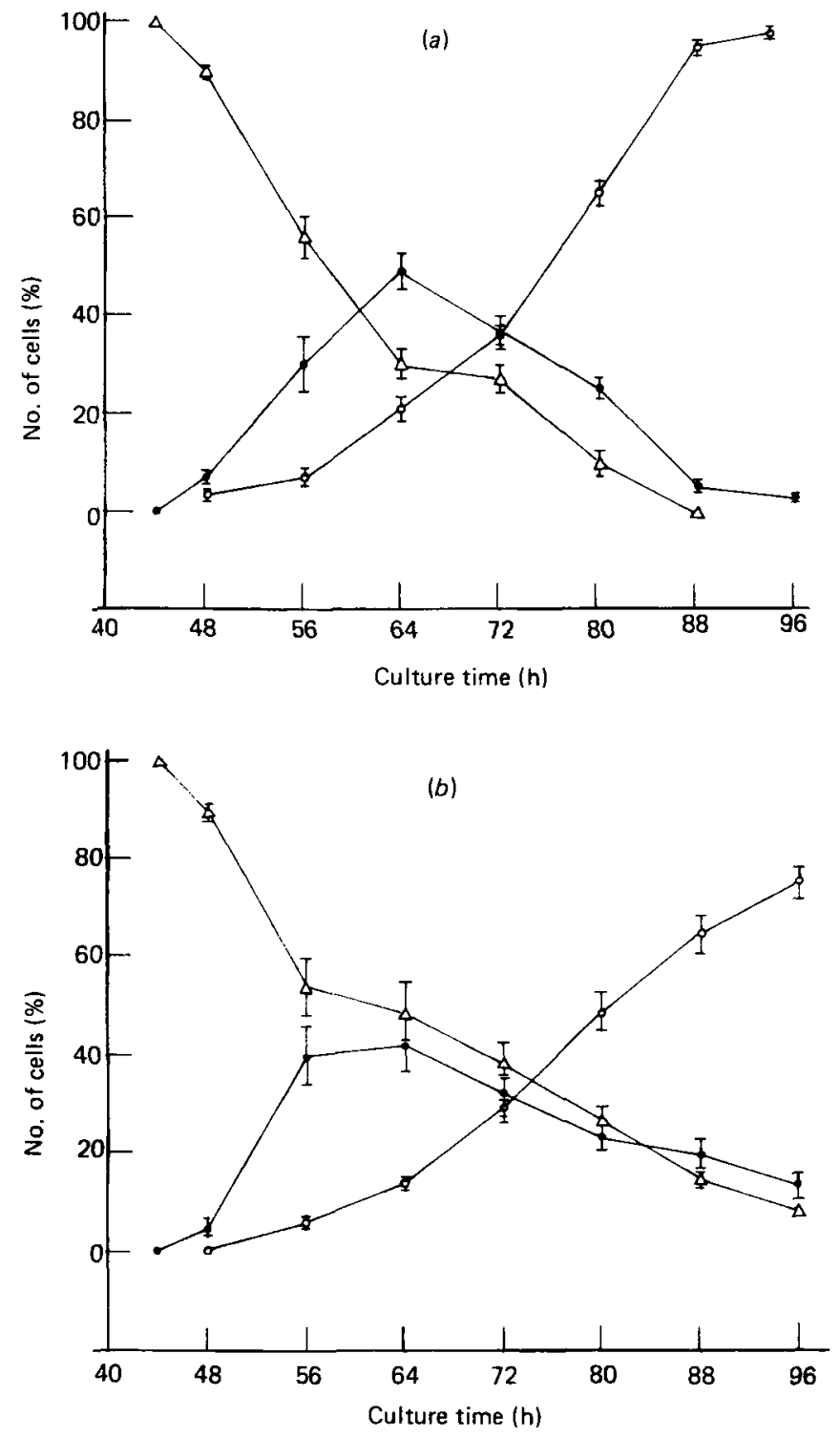

Fig. 1. Distribution of first- $(\Delta)$, second- $(O)$ and third- or subsequent- $(O)$ division metaphase cells in cultures of lymphocytes from $(a)$ normal and $(b)$ malnourished children at different culture times. Points are mean values and standard deviations, represented by vertical bars for five normal and six malnourished children.

difference was found in the slopes of regression lines for the disappearance of first-division cells between normal and kwashiorkor cultures $(P<0.01)$. The $t_{1}$ (time required for the conversion of $50 \%$ of cells to the next division) was calculated to be $10.46 \mathrm{~h}$ for normal and $15.05 \mathrm{~h}$ for kwashiorkor cultures, While analysing the results, pooled variations between groups were taken into consideration and the differences between individuals were not excluded from the total variation. 


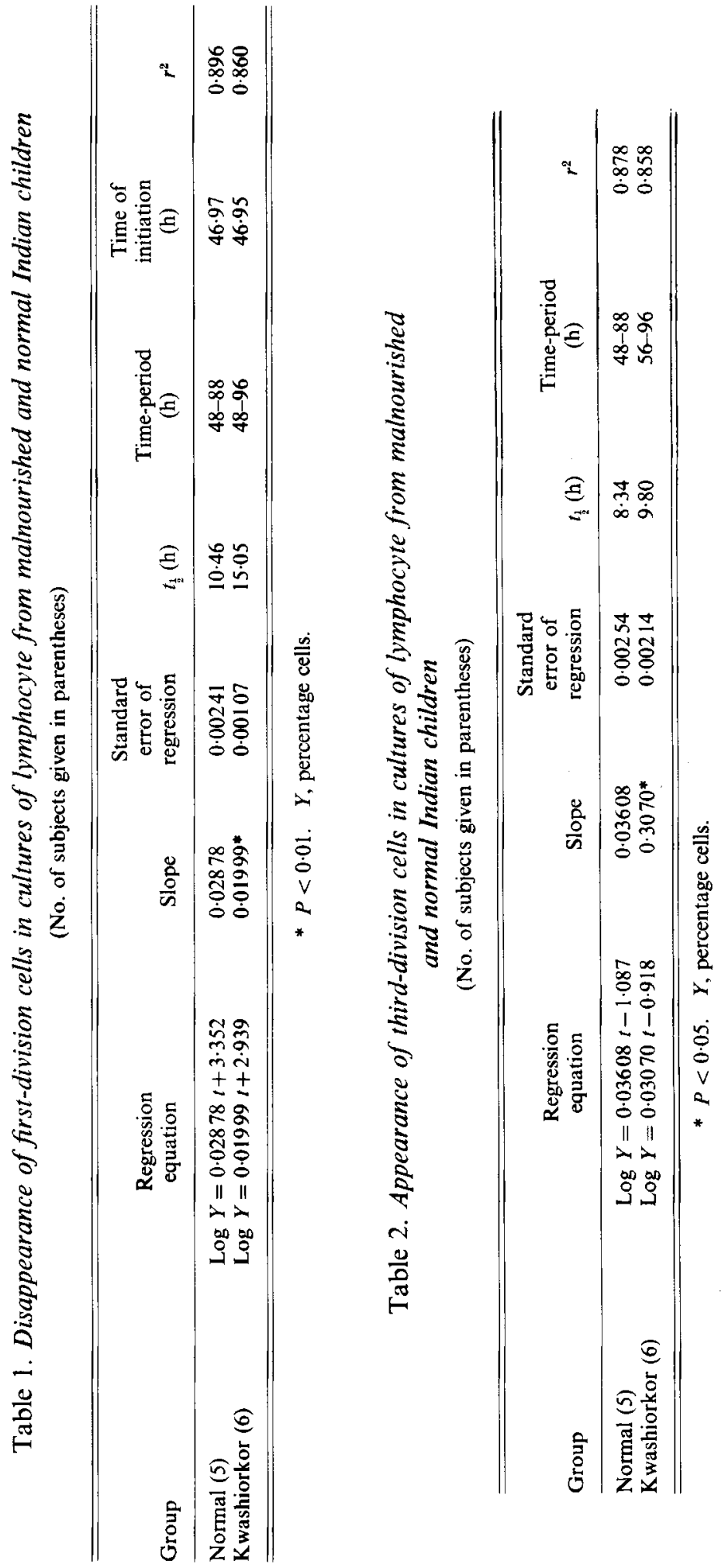


The slopes of the regression lines for the disappearance of third-division cells were 0.03608 and 0.03070 in normal and kwashiorkor cultures respectively. This difference was also significant $(P<0.05)$. A difference of approximately $1.5 \mathrm{~h}$ was found in the $t_{\frac{1}{2}}$ of these cells between normal and kwashiorkor cultures.

\section{DISCUSSION}

The present study has utilized a cytokinetic technique to analyse the impaired proliferative response of lymphocytes from malnourished children to PHA. The results of the study (it was expected), would help to understand whether or not alterations in cell-cycle durations have any role in the aetiology of the observed decline in lymphocyte activity to PHA in PEM.

Results presented here indicated that cell-cycle duration in lymphocyte cultures from kwashiorkor is prolonged. The order of increase in cell-cycle duration was found to be $4.5 \mathrm{~h}$ for first-division cells and $1.5 \mathrm{~h}$ for third-division cells. These findings were further supported by the flattened peak of second-division cells and decreased number of third-division cells in kwashiorkor cultures suggesting a longer cell-cycle duration.

There was no pronounced variability among cultures from different malnourished children in the distribution of first, second and third or subsequent division cells at various culture time points. So, the present finding of increased cell-cycle duration in cultures from malnourished children was not due to a relatively large increase in cell-cycle duration in a few patients but it was a phenomenon seen in all malnourished children.

There were significant differences in the slopes of regression lines for the first- and third-division cells between normal and kwashiorkor cultures. This could be due to a difference in the rate of PHA stimulation (Tice et al. 1979).

Another way of analysing the impaired proliferative response is to compare the culture times at which lines for different divisions cross each other (Purrott et al. 1980). The firstand third-division lines crossed at 69.5 and $74.8 \mathrm{~h}$ in normal and kwashiorkor cultures respectively providing further evidence for a cumulative delay of approximately $6.0 \mathrm{~h}$ between first- and third-division cell-cycle duration in kwashiorkor cultures.

From the present study it is difficult to comment on the duration of the individual phase of cell-cycle. Previous reports using labelling indices (Mathur \& Deo, 1976; Deo, 1978) in undernourished animals have shown that the $S$ phase is prolonged in all organs, $G_{2}$ is affected in some organs and $G_{1}$ is highly variable. So, the present finding, that prolonged lymphocyte division cycle in kwashiorkor cultures could be due to an increase in the duration of one or more phases of cell-division.

It is difficult to speculate on the factors responsible for the observed increase in cell-cycle duration in kwashiorkor cultures. Presence of an inhibitor in the plasma contributing to this observation may be excluded since lymphocytes isolated from the whole blood behaved similarly (results not presented here). The fact that lymphocytes from kwashiorkor were already activated in vivo because of infections, but fail to proliferate in a normal way in PHA-stimulated in vitro cultures, suggest that these cells have an intrinsic inability to respond to PHA.

The precise biological significance of increase in cell-cycle duration in malnourished children is not known. Delay in cell-cycle alone may not contribute to organ atrophy in PEM (Deo, 1978). On the other hand, increase in replication-cycle duration in PEM is corroborated by a decrease in DNA synthesis (Deo, 1978). Under these conditions, it was speculated that cell division would fail and chromosomes would become structurally abnormal (Armendares et al. 1971). In addition, the results of our unpublished data suggest that ultraviolet (u.v.) irradiation-treated cultures from malnourished children exhibit a much more prolonged cell-cycle duration than u.v.-untreated cultures. This would probably be 
contributing to the observed increase in u.v. induced chromosomal damage and mutagenesis in PEM (Murthy et al. 1982).

In summary, the results presented here indicate that cell-cycle duration is prolonged in kwashiorkor cultures. This would probably be contributing to the observed decrease in lymphocyte activity to PHA in PEM in general.

The authors wish to thank Dr S. G. Srikantia, Ex-Director, National Institute of Nutrition and Dr B. S. Narasinga Rao, Deputy Director, National Institute of Nutrition, for useful discussions, Dr P. Bhaskaram for clinical help, Mr U. Mallikarjuna Rao for help in mathematical analysis and Mr N. Anjani Kumar for technical assistance.

\section{REFERENCES}

Armendares, S., Salmanca, F. \& Frenk, S. (1971). Nature, Lond. 232, 271.

Bang, B. G., Mahalanabis, D., Mukherjee, K. L. \& Bang, F. (1975). Proc. Soc. exp. Biol. Med. 149, 199.

Burgess, B. J., Vos, G. H., Coovadia, H. M., Smythe, P. M., Parent, M. A. \& Loening, W. E. K. (1974). S. Afr. med. J. 48, 1870.

Chandra, R. K. (1974). Br, med. J. iji, 608.

Craig-Holmes, A. P. \& Shaw, M. W. (1976). Exp. Cell. Res. 99, 79.

Das, M., Stiehm, E. R., Borut, T. \& Feig, S. A. (1977). Am. J. clin. Nutr. 30, 1949.

Deo, M. G. (1978). Wld. Rev. Nutr. Diet. 32, 49.

Ferguson, A. C., Lawlor, G. J., Neumann, C. \& Stiehm, E. R. (1975). Fedn Proc. Fedn Am. Socs exp. Biol. 34, 227.

Giulotto, E., Mottura, A., Giorgi, R., DeCarli, L. \& Nuzzo, F. (1980). Mutation Res, $70,343$.

Gross, R. L. \& Newberne, P. M. (1980). Physiol. Rev. 60, 188.

Hatcher, N. H. \& Hook, E. B. (1976). Am. J. Human Genet. 28, 290.

Kulapongs, P. R., Suskind, R. M., Vithayasai, V. \& Olson, R. E. (1977). Malnutrition and the Immune Response, p. 99. New York: Raven.

Latt, S. A. (1974). Science, N.Y. 185, 74.

Mathur, M. \& Deo, M. G. (1976). Am. J. Path. 82, 9.

Murthy, P. B. K. \& Prema, K. (1979). Mutation Res. 68, 149.

Murthy, P. B. K., Tulpule, P. G. \& Rahiman, M. A. (1982). Pediatric Res. (In the Press).

Nelson, W. E. (1969). Textbook of Pediatrics, p. 12. Philadelphia: W. B. Saunders Co.

Perry, P. \& Wolff, S. (1974). Nature, Lond. 251, 156.

Purrott, R. J., Vulpis, N. \& Lloyd, D. C. (1980). Mutation Res. 69, 275.

Reddy, V., Jagadeesan, V., Raghuramulu, N., Bhaskaram, C. \& Srikantia, S. G. (1976). Am. J. clin. Nutr. 29, 3.

Schneider, E. L., Sternberg, H. \& Tice, R. R. (1977). Proc. natn. Acad. Sci. 74, 2041.

Schopfer, K. \& Douglas, S. D. (1976). Clin. Immun. Immunopath. 5, 21.

Sellmeyer, E., Bhettay, E., Truswell, A. S., Meyers, O. L. \& Hansen, J. D. L. (1972). Archs Dis. Child 47, 429.

Smythe, P. M., Brereton-Stiles, G. G., Grace, H. J., Mafoyane, A., Schonland, M., Coovadia, H. M., Loening, W. E. K., Parrent, M. A. \& Vos, C. H. (1971). Lancet ii, 939.

Tice, R. R., Chaillet, J. \& Schneider, E. L. (1975). Nature, Lond. 256, 642.

Tice, R. R., Thorne, P. \& Schneider, E. L. (1979). Cell Tissue Kinetics 12, 1.

Venkatachalam, P. S., Srikantia, S. G. \& Gopalan, C. (1954). Indian J. med. Res. 42, 555.

Wolff, S. \& Perry, P. (1974). Chromosoma 48, 341. 